\title{
TELAAH KOMPREHENSIF DIABETES MELITUS: KLASIFIKASI, GEJALA, DIAGNOSIS, PENCEGAHAN, DAN PENGOBATAN
}

\section{A Comprehensive Review of Diabetes Mellitus: Classification, Symptoms, Diagnosis, Prevention, and Treatment}

\author{
Dudi Hardianto \\ Pusat Teknologi Farmasi dan Medika, BPPT, Gedung LAPTIAB 610-612 Kawasan Puspiptek, \\ Tangerang Selatan, Banten 15314 \\ *Email: dudi.hardianto@bppt.go.id
}

\begin{abstract}
Diabetes mellitus is a metabolic disorder characterized by hyperglycemia. In general, diabetes is classified into type 1 diabetes mellitus (T1DM), type 2 diabetes mellitus (T2DM), gestational, and other specific diabetes. The causes of diabetes are genetic disorders and environmental. Common symptoms of diabetes include: polydipsia, polyphagia, glycosuria, polyuria, dehydration, fatigue, weight loss, reduced vision, cramps, constipation, and candida infection. Test for diagnosis of diabetes include: fasting plasma glucose test, plasma glucose test after 2 hours of $75 \mathrm{~g}$ oral glucose administration, the glycated hemoglobin test (HbA1C), and random blood glucose test. Prevention of T1DM is still difficult because of the limited knowledge of metabolic, genetic, and immunological processes in the development of T1DM. T2DM is prevented by lifestyle and medical intervention. Insulin is the only drug for T1DM, whereas T2DM is treated with metformin as drug's primary choice for reducing blood glucose levels.
\end{abstract}

Keywords: diabetes mellitus, classification, symptoms, diagnosis, treatment

\begin{abstract}
ABSTRAK
Diabetes melitus merupakan penyakit kelainan metabolisme yang ditandai dengan hiperglikemia. Secara umum, diabetes diklasifikasikan menjadi: diabetes melitus tipe 1 (DMT1), diabetes melitus tipe 2 (DMT2), gestasional, dan diabetes spesifik lain. Penyebab diabetes adalah kelainan genetik dan lingkungan. Gejala umum diabetes antara lain: polidipsia, polifagia, glikosuria, poliuria, dehidrasi, kelelahan, penurunan berat badan, daya penglihatan berkurang, kram, konstipasi, dan infeksi candida. Pemeriksaaan untuk diagnosis diabetes meliputi: pemeriksaan glukosa plasma saat puasa, pemeriksaan glukosa plasma setelah 2 jam pemberian glukosa oral $75 \mathrm{~g}$, pemeriksaan hemoglobin terglikasi ( $\mathrm{HbA1C})$, dan pemeriksaan glukosa darah acak. Pencegahan DMT1 masih sulit karena terbatasnya pengetahuan proses metabolisme, genetik, dan imunologi pada perkembangan DMT1. DMT2 dicegah dengan intervensi gaya hidup dan intervensi medis. Insulin merupakan satu-satunya obat untuk DMT1, sedangkan DMT2 diobati dengan metformin sebagai pilihan utama dan non obat untuk menurunkan kadar glukosa dalam darah.
\end{abstract}

Kata Kunci: diabetes melitus, diagnosis, gejala, klasifikasi, pengobatan 


\section{PENDAHULUAN}

Diabetes melitus (DM) atau diabetes merupakan penyakit kelainan metabolisme yang ditandai dengan hiperglikemia (kadar glukosa yang tinggi dalam darah) karena kekurangan insulin, resistensi insulin atau keduanya (Piero et al. 2014, Harikumar et al. 2015, Kharroubi dan Darwish 2015, Punthakee et al. 2018). Insulin adalah hormon yang diproduksi oleh sel $\beta$ pankreas untuk mengontrol glukosa darah melalui pengaturan penggunaan dan penyimpanan glukosa (Gupta et al. 2015, Asmat et al. 2016). Penyebab utama kekurangan insulin karena adanya kerusakan pada sel $\beta$ pankreas, yaitu sel yang berfungsi untuk memproduksi insulin (Baynest 2015, Asmat et al. 2016). Selain itu DM dapat juga disebabkan oleh resistensi insulin. Resistensi insulin adalah berkurangnya kemampuan insulin untuk merangsang penggunaan glukosa atau turunnya respons sel target, seperti otot, jaringan, dan hati terhadap kadar insulin fisiologis (Baynest 2015, Gupta et al. 2015, Asmat et al. 2016). Penyakit ini diketahui sudah ada sejak lama dan sudah dilaporkan dalam manuskrip Mesir sekitar 1500 SM (Allen dan Gupta 2019).

DM merupakan penyakit yang berbahaya, karena dalam jangka waktu lama dapat menyebabkan kerusakan jaringan, organ, disfungsi mata, ginjal, sistem saraf, dan pembuluh darah (Piero et al. 2014, Harikumar et al. 2015, Asmat et al. 2016). Prevalensi diabetes terus meningkat sehingga berdampak pada kehidupan dan kesejahteraan individu, keluarga, dan masyarakat di seluruh dunia. DM termasuk 10 besar penyakit penyebab kematian pada orang dewasa. Pada tahun 2017, pengeluaran biaya kesehatan secara global untuk diabetes mencapai USD 727 milyar (Duan et al. 2014, Wu et al. 2014, Saeedi et al. 2019).

Penderita diabetes meningkatkan risiko terjadinya penyakit lain seperti jantung, gangguan sistem kardiovaskular, obesitas, katarak, gangguan ereksi, penyakit hati, kanker, dan penyakit infeksi (Mane et al. 2012, Pasquel dan Umpierrez 2014, Rhee dan Kim 2015, Asmat et al. 2016, Kabel et al. 2017, Goguen dan Gilbert 2018, WHO 2019).

Pradiabetes adalah kondisi gangguan metabolisme yang ditandai dengan kadar glukosa darah berada di antara normal dan diabetes. Ciri-ciri pradiabetes mempunyai kadar glukosa puasa $(6,1-6,9 \mathrm{mmol} / \mathrm{L})$, kadar glukosa toleransi $(7,8-11,0 \mathrm{mmol} / \mathrm{L})$, dan kadar hemoglobin terglikasi atau hemoglobin yang berikatan dengan glukosa (HbA1C) 6,0-6,4\% (Punthakee et al. 2018). Penderita pradiabetes dapat menjadi diabetes tetapi sebagian besar akan kembali normal. Penderita pradiabetes meningkatkan risiko menderita penyakit kardiovaskular dan gangguan pada sistem saraf (Bergman et al. 2012, Chaudhury et al. 2017). Individu yang didiagnosis gangguan glukosa puasa dan gangguan toleransi glukosa memiliki risiko yang lebih tinggi menderita diabetes dan kardiovaskular dibandingkan individu dengan gangguan glukosa puasa atau gangguan toleransi glukosa saja. Di Amerika Serikat, penderita pradiabetes mencapai 86 juta. Negara lain yang mempunyai penderita pradiabetes tertinggi adalah Kuwait $(17,9 \%)$, Qatar (17,1\%), Uni Emirat Arab (16,6\%), dan Bahrain (16,3\%) (Kharroubi dan Darwish 2015, Chaudhury et al. 2017, Punthakee et al. 2018), sedangkan prediksi negara-negara dengan jumlah penderita DM terbanyak di dunia pada tahun 2030 adalah India (79,4 juta), Tiongkok (42,3 juta), Amerika Serikat (30,3 juta), Indonesia (21,3 juta), Pakistan (13,9 juta), Brazil (11,3 juta), Banglades (11,1 juta), Jepang (8,9 juta), Filipina (7,8 juta), dan Mesir (6,7 juta) (Baynest 2015).

Pradiabetes dan DMT2 merupakan manifestasi dari gangguan metabolit yang ditandai dengan obesitas, hipertensi, dan dislipidemia. Penderita gangguan metabolit kebanyakan menderita diabetes tetapi kadang tanpa menderita diabetes. Pengenalan lebih awal penderita pradiabetes penting agar individu tersebut merubah gaya hidup dan diberi terapi yang tepat sehingga mengurangi risiko terjadinya diabetes. Definisi dari gangguan atau sindrom metabolit adalah terdapatnya 3 atau lebih abnormalitas dari kriteria berikut: (1) lingkar pinggang, (2) total gliserida, (3) kadar kolesterol, (4) tekanan darah, (5) kadar glukosa puasa (Bergman et al. 2012, Punthakee et al. 2018).

\section{KLASIFIKASI DIABETES MELITUS}

Sistem klasifikasi diabetes yang ideal berdasarkan perawatan klinis, patologi, dan 
epidemiologi, tetapi saat ini belum memungkinkan karena keterbatasan pengetahuan dan sumber daya yang ada pada sebagian besar negara di dunia. Beberapa ahli mengusulkan pengelompokan berdasarkan perawatan klinis dan perlu tidaknya pemberian insulin terutama pada saat diagnosis (WHO 2019). Secara umum DM dikelompokkan menjadi 4 kelompok, yaitu: (1) DMT1, (2) DMT2, (3) gestasional, dan (4) diabetes spesifik lain (Olokoba et al. 2012, Wu et al. 2014, Gupta et al. 2015, Deepthi et al. 2017, Punthakee et al. 2018).

Penderita DMT1 ditemukan pada anak-anak dan remaja (Atkinson 2012, Bolla et al. 2015). Data penderita DMT1 secara global belum ada tetapi di negara maju penderita DMT1 meningkat antara 3 sampai $4 \%$ pada anak-anak, baik laki-laki maupun perempuan per tahunnya. DMT1 mengurangi harapan hidup sekitar 13 tahun di negara maju dan meningkat pada negara berkembang yang mempunyai akses terbatas untuk mendapatkan insulin. Diagnosis DMT1 dan DMT2 pada orang dewasa menjadi tantangan dan kesalahan diagnosis TDM1 menjadi TDM2 dan sebaliknya dapat mempengaruhi estimasi prevalensi. Dari hasil penelitian individu keturunan Eropa dalam Biobank di Inggris menunjukkan bahwa 42\% DMT1 terjadi setelah 31 tahun, dan $4 \%$ didiagnosis antara usia 31 sampai 60 tahun. Karakteristik klinik yang diamati meliputi

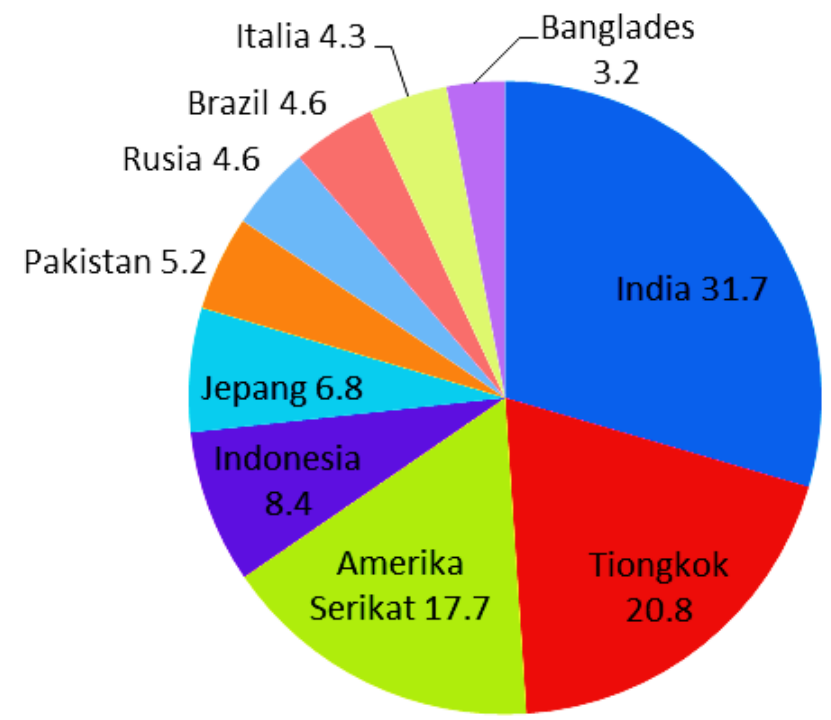

Gambar 1. Daftar negara dengan prediksi jumlah penderita diabetes pada tahun 2000 (dalam juta) (Baynest 2015) indeks massa tubuh, penggunaan insulin dalam 12 bulan setelah diagnosis, dan peningkatan risiko ketoasidosis diabetik (WHO 2019).

Umumnya DMT2 terjadi pada orang dewasa tetapi sekarang ini jumlah anak-anak dan remaja yang menderita DMT2 meningkat. DMT2 menjadi masalah kesehatan global dan serius yang berevolusi karena perubahan budaya, ekonomi dan sosial, populasi lanjut usia, peningkatan urbanisasi, perubahan pola makan (peningkatan konsumsi makanan olahan dan gula), obesitas, aktivitas fisik berkurang, gaya hidup tidak sehat, malnutrisi pada janin, paparan hiperglikemia pada janin saat kehamilan (Kabel et al. 2017).

Diabetes gestasional merupakan diabetes yang terjadi pada masa kehamilan (Punthakee et al. 2018). Biasanya terjadi pada trimester kedua dan ketiga saat kehamilan karena hormon yang disekresi plasenta menghambat kerja insulin. Sekitar $30-40 \%$ penderita diabetes gestasional berkembang menjadi DMT2 (Gupta et al. 2015). Diabetes gestasional terjadi pada 7\% kehamilan dan meningkatkan risiko kematian pada ibu dan janin. Diabetes spesifik lain merupakan diabetes berhubungan dengan genetik, penyakit pada pankreas, gangguan hormonal, penyakit lain atau pengaruh penggunaan obat (seperti glukokortikoid, pengobatan HIV/Aids, antipsikotik atipikal) (Gupta et al. 2015, Punthakee et al. 2018).

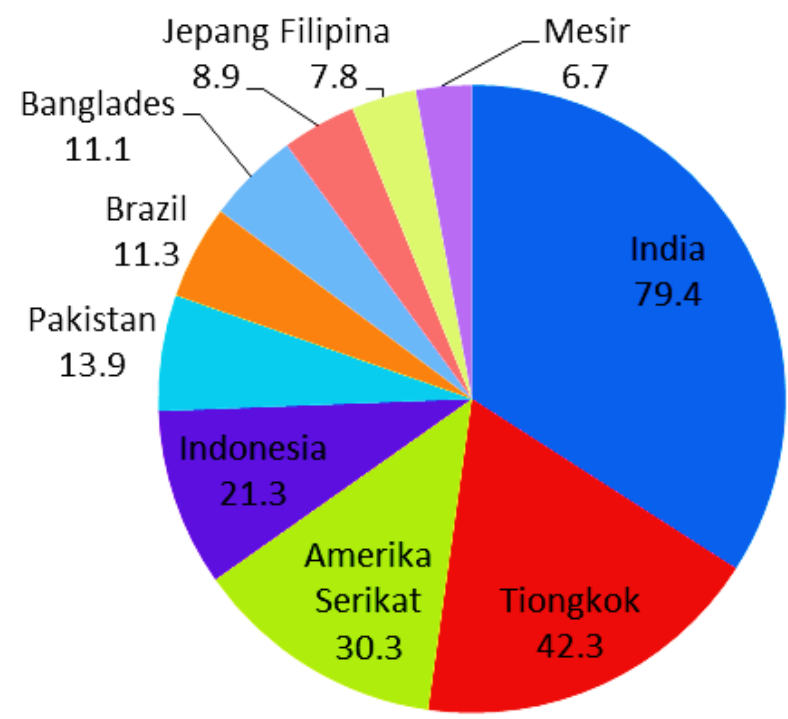

Gambar 2. Prediksi negara dengan jumlah penderita diabetes pada tahun 2030 (dalam juta) (Baynest 2015) 


\section{EPIDEMIOLOGI DIABETES MELITUS}

DM menjadi masalah kesehatan di seluruh dunia dan jumlah penderitanya terus meningkat (Gambar 1 dan 2). Berikut ini, negara dengan jumlah penderita diabetes terbanyak secara berurutan, yaitu India, Tiongkok, dan Amerika Serikat (Al-Lawati 2017, Uusitupa et al. 2019). Di India terjadi peningkatan penderita diabetes 5 kali lipat dari tahun 1970 sampai dengan tahun 2000 . Di Indonesia, pasien diabetes mencapai 8,5 juta orang pada tahun 2013 (Suprapti et al. 2017). Penduduk Timur Tengah dan Afrika Utara mempunyai prevalensi DM 10,7\%, sedangkan penduduk Amerika Utara dan Karibia 11,5\% (Al-Lawati 2017). Pada tahun 2017, jumlah penderita diabetes di Eropa mencapai 66 juta orang dan diprediksi akan menjadi 81 juta orang pada tahun 2045 (Uusitupa et al. 2019). Pada tahun 2012, sekitar 1,2 juta orang meninggal akibat DM (Okur et al. 2017). Diperkirakan lebih dari 425 juta penduduk di dunia menderita DM pada tahun 2017 (Silver et al. 2018), dan diprediksi mencapai 592 juta orang pada tahun 2035 (Suprapti et al. 2017).

Diabetes menyebabkan kematian 4 juta orang setiap tahunnya dan International Diabetes Federation (IDF) memperkirakan bahwa biaya perawatan kesehatan global tahunan untuk diabetes sebesar $\$ 850$ miliar pada tahun 2017. Efek diabetes selain berpengaruh pada individu juga mempengaruhi keluarga dan masyarakat sekitar serta sosial-ekonomi yang luas, terutama di negara-negara berpenghasilan rendah dan menengah (Setty et al. 2016, WHO 2019).

\section{PATOGENESIS DIABETES MELITUS}

DMT1 ditandai dengan rusaknya sel-sel penghasil insulin (sel $\beta$ pankreas) karena autoimun pada organ pankreas oleh sel $T$ (CD4+ dan CD8+) dan makrofag (Baynest 2015, Asmat et al. 2016, Paschou et al. 2018, Pathak et al. 2019, Janez et al. 2020). Karakteristik DMT1 sebagai penyakit autoimun antara lain: (1) adanya sel imuno dan asesoris dalam sel pankreas serta adanya autoantibodi spesifik dalam sel pankreas, (2) perubahan imunoregulasi yang dimediasi sel T, (3) keterlibatan monokin dan sel TH1 untuk memproduksi interleukin dalam proses penyakit, (4) respon terhadap imunoterapi, (5) sering terjadi penyakit autoimun pada organ spesifik lain pada individu atau keluarganya (Baynest 2015).

Tingkat kerusakan sel $\beta$ pankreas tiap individu berbeda. DMT1 umumnya terjadi pada anak-anak tetapi dapat juga terjadi pada orang dewasa. Pasien anak-anak dan remaja menunjukkan gejala ketoasidosis sedangkan pada orang dewasa dapat mempertahankan fungsi sel $\beta$ pankreas untuk mencegah ketoasidosis selama bertahun-tahun. Rendah atau tidak terdeteksinya kadar C-peptida dalam darah atau urin merupakan manifestasi klinis untuk mendeteksi sedikit atau tidak adanya sekresi insulin pada DMT1. Sekitar 70-90\% DMT1 memberikan diagnosis positif terhadap reaksi autoimun untuk asam glutamat dekarboksilase, antigen islet 2, dan transporter Zn (WHO 2019).

Sekitar $85 \%$ pasien DMT1 memiliki antibodi sel islet pankreas yang bersirkulasi dan mayoritas memiliki antibodi anti-insulin yang dapat dideteksi sebelum menerima terapi insulin (Baynest 2015). Ciri lain DMT1 adalah abnormalitas sel a pankreas dan sekresi glukagon yang berlebihan. Biasanya hiperglikemia menyebabkan berkurangnya sekresi glukagon tetapi pada penderita DMT1 sekresi glukagon tidak tertekan oleh hiperglikemia. Kadar glukagon yang meningkat akan memperburuk gangguan metabolit karena defisiensi insulin. Kekurangan insulin juga dapat menyebabkan lipolisis dan peningkatan asam lemak bebas dalam plasma, menekan metabolisme glukosa dalam jaringan perifer seperti otot rangka. Penyebab DMT1 adalah gangguan genetik dan faktor lingkungan, seperti infeksi virus, racun, dan makanan dapat mempengaruhi perkembangan dan autoimun pada sel $\beta$ pankreas (Forbes dan Cooper 2013, Forouhi dan Wareham 2014).

DMT2 terjadi karena resistensi insulin dan gangguan sekresi insulin karena kelainan fungsi sel $\beta$. Resistensi insulin ditandai dengan berkurangnya kemampuan insulin untuk menyeimbangkan kadar glukosa darah karena berkurangnya sensitivitas jaringan sehingga meningkatkan produksi insulin oleh sel $\beta$ pankreas (Baynest 2015, Kumar et al. 2017, Basukala et al. 2018, WHO 2019). Resistensi insulin dan hiperinsulinemia menyebabkan gangguan toleransi glukosa. Sel islet akan meningkatkan jumlah insulin 
yang disekresi untuk mengatasi resistensi insulin. Hiperinsulinemia, yang terjadi pada tahap awal dan menengah penyakit, merupakan pendorong DMT2 (Bolla et al. 2015, Crofts et al. 2015).

Umumnya penderita DMT2 mempunyai berat badan berlebih atau obesitas sehingga insulin tidak dapat bekerja secara optimal dan sebagai kompensasinya diproduksi insulin yang lebih banyak. Kelainan fungsi sel $\beta$ pada DMT2 pada orang Asia lebih banyak dibandingkan dengan orang Eropa. DMT2 sering tidak terdiagnosis karena hiperglikemia yang tidak cukup parah untuk menunjukkan gejala diabetes (Bolla et al. 2015, Kabel et al. 2017, WHO 2019).

Faktor yang meningkatkan risiko DMT2 antara lain usia, obesitas, gaya hidup, ras, dan penderita diabetes gestasional (WHO 2019). Obesitas berkontribusi sebesar 55\% dari kasus DMT2. Peningkatan obsesitas pada rentang tahun 1960 sampai dengan tahun 2000 menyebabkan kasus DMT2 pada anak-anak dan remaja. Racun/toksin yang berasal dari lingkungan, seperti adanya senyawa bisfenol A sebagai komponen plastik di dalam urin dapat menginduksi terjadinya DMT2 (Olokoba et al. 2012).

\section{KOMPLIKASI DIABETES MELITUS}

Berkurangnya sekresi insulin dan gangguan metabolisme karbohidrat, lemak, dan protein mengakibatkan komplikasi DM. Pengontrolan kadar glukosa darah pada penderita diabetes dapat mencegah terjadinya komplikasi (Chatterjee dan Davies 2015, Allen dan Gupta 2019).

Komplikasi diabetes akan meningkatkan morbilitas dan kematian (Papatheodorou et al. 2016). Beberapa komplikasi penyakit akibat DM, di antaranya adalah penyakit kardiovaskular, gangguan ginjal, peradangan, dan obesitas. Studi epidemiologis menunjukkan bahwa jenis kelamin, usia, dan latar belakang etnis merupakan faktor penting dalam perkembangan komplikasi DM. Penderita diabetes memiliki risiko komplikasi yang menyebabkan terjadinya kematian (Olokoba et al. 2012). Secara umum komplikasi yang terjadi dikelompokkan menjadi 2, yaitu: (1) komplikasi akut metabolik, berupa gangguan metabolit jangka pendek seperti hipoglikemia, ketoasidosis, dan hiperosmolar; dan (2) komplikasi lanjut, komplikasi jangka panjang yang mengakibatkan makrovaskular (penyakit jantung koroner, penyakit pembuluh darah perifer dan stroke), mikrovaskular (nefropati, retinopati dan neuropati), dan gabungan makrovaskular dan mikrovaskular (diabetes kaki). Penyebab kematian pada orang tua penderita diabetes akibat degradasi makrovaskular lebih banyak dibandingkan dengan mikrovaskular (Mane et al. 2012, Pasquel dan Umpierrez 2014, Rhee dan Kim 2015, Asmat et al. 2016, Kabel et al. 2017, Goguen dan Gilbert 2018).

\section{GEJALA DIABETES MELITUS}

Pada tahap awal DMT2 biasanya tidak menunjukkan gejala diabetes. Gejala umum penderita diabetes adalah sebagai berikut: (1) meningkatnya rasa haus karena air dan elektrolit dalam tubuh berkurang (polidipsia), (2) meningkatnya rasa lapar karena kadar glukosa dalam jaringan berkurang (polifagia), (3) kondisi urin yang mengandung glukosa biasanya terjadi ketika kadar glukosa darah $180 \mathrm{mg} / \mathrm{dL}$ (glikosuria), (4) meningkatkan osmolaritas filtrat glomerulus dan reabosorpsi air dihambat dalam tubulus ginjal sehingga volume urin meningkat (poliuria), (5) dehidrasi karena meningkatnya kadar glukosa menyebabkan cairan ekstraselular hipertonik dan air dalam sel keluar, (6) kelelahan karena gangguan pemanfaatan $\mathrm{CHO}$ mengakibatkan kelelahan dan hilangnya jaringan tubuh walaupun asupan makanan normal atau meningkat, (7) kehilangan berat badan disebabkan oleh kehilangan cairan tubuh dan penggunaan jaringan otot dan lemak akan diubah menjadi energi, (8) dan gejala lain berupa daya penglihatan berkurang, kram, konstipasi, dan penyakit infeksi candidiasis (Mane et al. 2012, Baynest 2015, Kharroubi dan Darwish 2015).

Pada beberapa penderita diabetes tidak ada gejala sehingga memperburuk kondisi penderita diabetes dan diperkirakan $30-80 \%$ penderita diabetes tidak terdiagnosis. Penderita diabetes yang tidak diobati dengan tepat dapat menyebabkan pingsan, koma, dan kematian (Kharroubi dan Darwish 2015). 
Tabel 1. Kriteria diagnosis untuk pradiabetes dan diabetes

\begin{tabular}{lccc}
\hline Kriteria & Normal & Pradiabetes & Diabetes \\
\hline Kadar glukosa puasa & $\leq 99 \mathrm{mg} / \mathrm{dL}$ & $100-125 \mathrm{mg} / \mathrm{dL}(5,6-6,9 \mathrm{mmol} / \mathrm{L})$ & $\geq 126 \mathrm{mg} / \mathrm{dL}(7,0 \mathrm{mmol} / \mathrm{L})$ \\
Kadar glukosa toleransi & $<139 \mathrm{mg} / \mathrm{dL}$ & $140-199 \mathrm{mg} / \mathrm{dL}(7,8-11,0 \mathrm{mmol} / \mathrm{L})$ & $>200 \mathrm{mg} / \mathrm{dL}(11,1 \mathrm{mmol} / \mathrm{L})$ \\
Kadar hemoglobin terglikasi & $<5,6 \%$ & $5,7-6,4 \%$ & $>6,5 \%$ \\
\hline
\end{tabular}

\section{DIAGNOSIS DIABETES MELITUS}

Diabetes dapat didiagnosis dengan 4 jenis pemeriksaan, yaitu: (1) pemeriksaan glukosa plasma saat puasa, (2) pemeriksaan glukosa plasma setelah 2 jam pemberian glukosa oral $75 \mathrm{~g}$ atau pemeriksaan toleransi, (3) pemeriksaan $\mathrm{HbA} 1 \mathrm{C}$, dan (4) pemeriksaan glukosa darah acak (Tabel 1). Individu dengan nilai glukosa plasma saat puasa $\geq 7,0 \mathrm{mmol} / \mathrm{L}(126 \mathrm{mg} / \mathrm{dL})$, glukosa plasma setelah 2 jam atau setelah tes toleransi glukosa oral $75 \mathrm{~g} \geq 11,1 \mathrm{mmol} / \mathrm{L}$ $(200 \mathrm{mg} / \mathrm{dL})$, hemoglobin A1C $(\mathrm{HbA} 1 \mathrm{C}) \geq$ $6,5 \%(48 \mathrm{mmol} / \mathrm{mol})$, dan glukosa darah acak $\geq 11,1 \mathrm{mmol} / \mathrm{L}(200 \mathrm{mg} / \mathrm{dL})$ dengan adanya tanda dan gejala dianggap memiliki diabetes (Baynest 2015, Punthakee et al. 2018, WHO 2019). Jika nilai tinggi terdeteksi pada individu tanpa gejala, harus diulang dengan pemeriksaan yang sama pada hari berikutnya untuk mengkonfirmasi diagnosis. Diagnosis diabetes memiliki implikasi penting bagi individu, mempengaruhi pekerjaan, asuransi kesehatan dan jiwa, status mengemudi, peluang sosial dan budaya, konsekuensi etis dan hak asasi manusia (WHO 2019).

Pemeriksaan $\mathrm{HbA} 1 \mathrm{C}$ berfungsi untuk mengukur jumlah hemoglobin yang berikatan dengan glukosa selama 3 bulan terakhir. $\mathrm{HbA1C}$ kurang sensitif untuk mendiagnosis diabetes dibandingkan dengan pemeriksaan glukosa tradisional karena beberapa penyakit, ketinggian tempat tinggal, etnis, usia, dan penyakit tertentu dapat mempengaruhi hasil pemeriksaan $\mathrm{HbA} 1 \mathrm{C}$. Pemeriksaan $\mathrm{HbA} 1 \mathrm{C}$ tidak dapat digunakan pada individu dengan hemoglobinopati, anemia defisiensi besi atau hemolitik, anemia tanpa defisiensi besi, penyakit hati, dan gangguan ginjal yang parah. Hubungan antara kadar glukosa dan $\mathrm{HbA1C}$ bervariasi antara orang yang hidup di lokasi dengan ketinggian ekstrim. Beberapa etnis menunjukkan bahwa Afrika Amerika, Indian Amerika, Hispanik, dan Asia memiliki nilai
HbA1C sampai $0,4 \%$ lebih tinggi dibandingkan dengan orang kulit putih non Hispanik pada tingkat glikemia yang sama. Nilai $\mathrm{A} 1 \mathrm{C}$ dipengaruhi oleh usia, naik hingga $0,1 \%$ per dekade kehidupan. HbA1C tidak direkomendasikan digunakan untuk diagnosis pada anak-anak dan remaja, wanita hamil, penderita fibrosis sistik atau DMT1 (Punthakee et al. 2018). Pengujian $\mathrm{HbA1C}$ mempunyai keunggulan antara lain adalah kenyamanan karena tidak mengharuskan pasien untuk puasa (pemeriksaan glukosa saat puasa).

\section{PENCEGAHAN DIABETES MELITUS}

Pencegahan untuk DMT1 masih sulit karena terbatasnya pengetahuan proses metabolisme, genetik, dan imunologi pada perkembangan DMT1 (Chatterjee dan Davies 2015). Pencegahan DMT2 dapat dilakukan dengan intervensi gaya hidup dan intervensi farmakologi (Chatterjee dan Davies 2015, Messina et al. 2017, Wang et al. 2018, Uusitupa et al. 2019).

\section{Perubahan gaya hidup}

Pencegahan DMT2 dilakukan dengan gaya hidup atau perilaku hidup sehat dengan diet dan olah raga. Diet dilakukan dengan penurunan kalori individu dan memonitor penanda kardiometabolik seperti tekanan darah, lemak, dan peradangan. Diet dapat membantu mengontrol kadar glukosa darah, menjaga tekanan darah, kadar lemak darah dan berat badan normal, tidur yang cukup, dan meningkatkan kualitas kesehatan (MarinPenalver et al. 2016, Russell et al. 2016). Olahraga dapat meningkatkan sensitivitas insulin, mengontrol kadar glukosa darah, memperbaiki profil lemak dan tekanan darah, menurunkan berat badan, mengurangi risiko penyakit kardiovaskular, dan mengurangi depresi (Marin-Penalver et al. 2016).

Penurunan berat badan terstruktur, aktivitas fisik, dan diet sangat penting untuk 
mereka yang berisiko tinggi menderita DMT2 dengan memiliki berat badan berlebih atau obesitas. Pola makan bermanfaat bagi penderita pradiabetes meliputi pola makan rendah kalori dan rendah lemak. Penelitian tambahan diperlukan untuk rencana pola makan rendah karbohidrat bagi penderita pradiabetes. Pola makan yang terukur dengan mengkonsumsi makanan berserat tinggi, biji-bijian, kacang-kacangan, buahbuahan dan sayuran, dan mengurangi makanan olahan juga penting. Asupan kacang, beri, yogurt, kopi, dan teh dapat menurunkan risiko DMT2, tetapi daging merah dan gula meningkatkan risiko obesitas dan DMT2. Pola makan yang menurunkan kadar $\mathrm{HbA} 1 \mathrm{C}$ penting bagi penderita pradiabetes (Olokoba et al. 2012, Kolb dan Martin 2017).

Berikut ini adalah gaya hidup yang berhubungan dengan tingkat risiko diabetes menurut ahli epidemiologi (Kolb dan Martin 2017): (1) rutin memakan makanan yang tidak atau kurang berserat meningkatkan risiko diabetes 3 kali lipat, (2) konsumsi minuman manis dengan gula meningkatkan risiko diabetes sebesar $20-30 \%$, (3) sedikit aktivitas fisik meningkatkan risiko $40 \%$, (4) menonton TV berkepanjangan (meningkatkan risiko 3\% per jam menonton televisi), (5) paparan lalu lintas (kebisingan dan partikel halus) meningkatkan risiko 20 $40 \%$, untuk kebisingan lebih dari $10 \mathrm{~dB}$ atau $10 \mu \mathrm{g} / \mathrm{m}^{3}$ lebih banyak debu halus, (6) merokok meningkatkan risiko $30-60 \%$ untuk perokok berat, (7) durasi tidur yang pendek meningkatkan risiko 9\% per jam durasi tidur singkat, (8) stres atau depresi rendah meningkatkan risiko diabetes tergantung pada tingkat stres atau depresi, (9) posisi sosial ekonomi rendah meningkatkan risiko sebesar 40-100\%, (10) pertambahan berat badan dan lingkar pinggang meningkatkan risiko diabetes.

\section{Intervensi medis}

Salah satu faktor utama penyebab DMT2 adalah obesitas. Pencegahan dan pengobatan obesitas dapat mencegah terjadinya DMT2 (Bolla et al. 2015, Kabel et al. 2017). Penggunaan obat-obatan dan operasi bariatrik pada penderita obesitas dapat mengurangi terjadinya DMT2 (Aktar et al. 2017, Akcay et al. 2019).
Obat-obatan untuk obesitas seperti: orlistat, sibutramin, lorkaserin, fentermin, bupropion dan naltrekson. Orlistat mempunyai mekanisme kerja berikatan dengan lipase sehingga menghambat aktivitas lipase hingga 30\%. Hasil uji klinis orlistat menurunkan $3 \mathrm{~kg}$ atau $3 \%$ dibandingkan dengan plasebo. Mekanisme kerja sibutramin melalul penghambatan norepinefrin dan serotonin. Obat ini dapat menurunkan $5 \mathrm{~kg}$ atau 4\% dibandingkan dengan plasebo. Lorkaserin merupakan agonis reseptor serotonin 2C dengan efek hipofagia (meningkatnya rasa kenyang). Obat ini mampu menurunkan berat badan sampai $5 \%$ setelah 12 minggu pemakaian. Fentermin merupakan agonis norepinefrin yang mempunyai mekanisme kerja menekan nafsu makan pada sistem saraf pusat. Kombinasi bupropion dan naltrekson dapat menurunkan berat badan. Bupropion merupakan inhibitor nonselektif terhadap dopamin dan norepinefrin, sedangkan naltrekson merupakan antagonis reseptor opioid. Kombinasi obat ini dapat menstimulasi pelepasan melanosit hormon sehingga dapat menekan rasa lapar dan mengontrol berat badan (Aktar et al. 2017). Operasi bariatrik adalah operasi mengubah sistem pencernaan sehingga mengurangi penyerapan makanan. Operasi ini terbukti efektif menurunkan berat badan dan meningkatkan kontrol kadar glukosa darah (Akcay et al. 2019).

\section{PENGOBATAN}

Tujuan dari pengobatan diabetes adalah mengendalikan glukosa darah untuk mencegah terjadinya komplikasi yang menyebabkan kematian. Pengobatan diabetes dilakukan dengan 2 pendekatan yaitu: (1) penggunaan obat dan (2) pengunaan non obat (Harikumar et al. 2015).

\section{Obat}

DMT1 merupakan diabetes yang disebabkan oleh kekurangan produksi insulin akibat rusaknya sel $\beta$ pankreas (sel yang berfungsi untuk memproduksi insulin) sehingga diobati insulin dari luar tubuh seumur hidup (Sorli 2014, Janez et al. 2020). Umumnya obat DMT2 diberikan secara oral. Metformin dan sulfonilurea merupakan antidiabetes yang sudah digunakan sejak 
Tabel 2. Farmakokinetik analog insulin (Patil et al. 2017)

\begin{tabular}{|c|c|c|c|}
\hline Jenis & Onset & Puncak & Durasi \\
\hline \multicolumn{4}{|l|}{ Bekerja cepat: } \\
\hline Aspart & 15 menit & 1-3 jam & 3-5 jam \\
\hline Lispro & 15 menit & $30-90$ menit & 3-5 jam \\
\hline Glulisine & $15-30$ menit & $30-60$ menit & 4 jam \\
\hline \multicolumn{4}{|l|}{ Bekerja pendek: } \\
\hline Actrapid & $30-60$ menit & 2-4 jam & 5-8 jam \\
\hline \multicolumn{4}{|l|}{ Bekeria Menengah: } \\
\hline $\mathrm{NPH}$ & 1-2 jam & 4-10 jam & 14 jam atau lebih \\
\hline \multicolumn{4}{|l|}{ Bekerja Panjang: } \\
\hline Detemir & 3-4 jam & 6-8 Jam & 6-23 jam \\
\hline Glargine & 90 menit & - & 24 jam \\
\hline \multicolumn{4}{|l|}{ Bekerja Sangat Panjang: } \\
\hline Degludec & 30-90 menit & - & Sampai 42 jam \\
\hline \multicolumn{4}{|l|}{ Campuran: } \\
\hline NPH-Lispro/NPH-Aspart & $15-30$ menit & 2 puncak & 14-24 jam \\
\hline NPH-Regular & 30-60 menit & 2 puncak & 14-24 jam \\
\hline
\end{tabular}

tahun 1950. Pilihan utama untuk pengobatan DMT2 adalah metformin. Metformin menjadi pilihan utama karena efektif dengan 2 mekanisme kerja, yaitu mengurangi sekresi glukosa hepatik dan meningkatkan penyerapan glukosa, aman untuk penderita DM tanpa gangguan hati dan ginjal, dan harganya murah. Pemilihan obat DM berdasarkan pada jenis diabetes, usia, situasi, dan faktor lainnya (Olokoba et al. 2012, Chatterjee dan Davies 2015, Gupta et al. 2015, Harikumar et al. 2015, MarinPenalver et al. 2016).

\section{Insulin}

Insulin biasanya diberikan secara subkutan dengan suntikan atau pompa insulin. Insulin dapat diberikan juga secara intravena. Saat ini tersedia insulin manusia dan analog insulin (Janez et al. 2020). Ada beberapa analog insulin (Tabel 2), seperti: (1) analog insulin yang bekerja cepat (memberikan efek dimulai dari 4 sampai 20 menit dan puncak antara 20 sampai 30 menit) seperti: Aspart (Novorapid ${ }^{\mathrm{TM}}$, Fiasp ${ }^{\mathrm{TM}}$ ), Lispro (Humalog $^{\mathrm{TM}}$, Liprolog ${ }^{\mathrm{TM}}$, Admelog ${ }^{\mathrm{TM}}$ ), Glulisine (Apidra ${ }^{\mathrm{TM}}$ ), (2) analog insulin yang bekerja dalam jangka waktu pendek (efek mulai dari 30 menit dan puncak 2-4 jam) seperti Insulin (Actrapid ${ }^{\mathrm{TM}}$, Humulin $\mathrm{S}^{\mathrm{TM}}$, Insuman Rapid ${ }^{\mathrm{TM}}$ ), (3) analog insulin yang bekerja dalam jangka waktu menengah (onset puncak antara 4-6 jam dan efek 14-16 jam) seperti: Insulin Isophane (Insulatard ${ }^{\mathrm{TM}}$, Insuman Basal ${ }^{\mathrm{TM}}$, Novolin $\mathrm{N}^{\mathrm{TM}}$, Humulin $\mathrm{N}^{\mathrm{TM}}$, (4) analog insulin yang bekerja dalam jangka waktu panjang (efek 24-36 jam) seperti: Glargine (Lantus ${ }^{\mathrm{TM}}$, Abasaglar ${ }^{\mathrm{TM}}$ ), Detemir (Levemir ${ }^{\mathrm{TM}}$ ), (5) dan analog insulin yang bekerja dalam jangka waktu sangat panjang (efek mulai dari 30-90 menit dan berlangsung sampai 42 jam) seperti: Degludec (Tresiba ${ }^{\mathrm{TM}}$ ).

Penderita DMT2 diobati dengan obat hiperglikemik oral dan perubahan gaya hidup (Patil et al. 2017, Stubbs et al. 2017, Pathak et al. 2019). Penderita DMT2 umumnya tidak memerlukan terapi dengan insulin dan hanya diberi obat oral seperti sulfonilurea, biguanida, tiazolidinedion, inhibitor $\alpha$ glikosidase (Tabel 3). Pengobatan dengan insulin diperlukan dalam kasus untuk menurunkan glukosa darah sehingga tidak terjadi komplikasi kronis, memiliki kontrol darah yang buruk $(\mathrm{HbA1C}>7,5 \%$ atau kadar glukosa puasa $\geq 250 \mathrm{mg} / \mathrm{dL}$ ), riwayat pankreatomi, mengalami DMT2 selama 10 tahun, penderita hepatitis kronis, TBC paru, patah tulang, kanker, dan mengurangi efek samping obat oral (Sorli 2014, Bolla et al. 2015, Harikumar et al. 2015, Patil et al. 2017, Suprapti et al. 2017, Pathak et al. 2019, Wondafrash et al. 2020). Insulin diberikan untuk menormalkan kadar glukosa plasma sehingga mencegah komplikasi diabetes (Harikumar et al. 2015). 


\section{Sulfonilurea}

Sulfonilurea (glibenklamid, gliklazid, glimepirid, gliburid, glipizid, tolbutamid) adalah obat antihiperglikemik oral yang pertama digunakan dan merupakan obat pilihan kedua untuk DMT2. Obat ini biasanya digunakan untuk DMT2 yang lanjut usia. Mekanisme kerjanya meningkatkan sekresi insulin dengan bekerja langsung pada saluran KATP sel $\beta$ pankreas. Pasien yang menggunakan obat ini dapat mengalami hipoglikemia sehingga pasien harus mengetahui pola makan yang baik dan gejala hipoglikemia (Gupta et al. 2015, Harikumar et al. 2015, MarinPenalver et al. 2016). Gliburid menyebabkan hipoglikemia lebih tinggi dibandingkan dengan glipizid. Hipoglikimia yang terjadi pada penderita lanjut usia akan meningkatkan risiko terjadinya kerusakan fungsi ginjal (Olokoba et al. 2012).

\section{Meglitinide}

Meglitinide (Repaglinid dan Nateglinid) merupakan obat antihiperglikemik oral dengan mekanisme kerja membantu pankreas untuk memproduksi insulin dengan menutup saluran kalium dan membuka saluran dari sel $\beta$ pankreas sehingga meningkatkan sekresi insulin. Obat ini jarang digunakan karena kerja obat yang singkat sehingga pemberian obat lebih sering (Harikumar et al. 2015, Marin-Penalver et al. 2016, Stubbs et al. 2017). Repaglinid sebagian besar dimetabolime di hati dan sisanya disekresikan melalui ginjal (Olokoba et al. 2012).

\section{Biguanid}

Biguanid (Metformin, Fenformin, Buformin) merupakan obat anti diabetes dengan mekanisme kerja mengurangi sekresi glukosa hepatik dan meningkatkan penyerapan glukosa perifer termasuk otot rangka. Metformin merupakan obat hipoglisemik utama untuk penderita DMT2 pada anak-anak dan remaja serta sesuai untuk pasien yang kelebihan berat badan (Gupta et al. 2015, Harikumar et al. 2015, Marin-Penalver et al. 2016, Stubbs et al. 2017). Obat ini sebaiknya tidak digunakan oleh pasien dengan gangguan fungsi hati atau ginjal. Penggunaan pada penderita lanjut usia dapat menyebabkan terjadinya asidosis (Olokoba et al. 2012).

\section{Tiazolidinedion}

Tiazolidinedion

(Rosiglitazon,

Pioglitazon dan Troglitazon) dikenal dengan sebutan glitazon. Obat ini bekerja membentuk ikatan dengan peroxisome proliferator-activated receptor-gamma (PPAR-y) yang mengatur metabolisme glukosa dan lemak serta mempengaruhi gen sensitivitas insulin sehingga meningkatkan penggunaan glukosa oleh sel. Obat ini mengurangi komplikasi mikrovaskular sebesar 2,6\% (Gupta et al. 2015, Harikumar et al. 2015). Pada beberapa tahun terakhir, penggunaan obat ini dikurangi karena meningkatkan risiko kematian pada penderita penyakit kardiovaskular, edema, patah tulang, gagal jantung, dan kanker (Olokoba et al. 2012, Stubbs et al. 2017).

\section{Inhibitor a-glikosidase}

Inhibitor $\alpha$-glikosidase (Miglitol, Akarbose, Voglibose) tidak memiliki efek langsung pada sekresi atau sensitivitas insulin. Senyawa ini memperlambat pencernaan pati di dalam usus halus sehingga glukosa dari pati lambat memasuki aliran darah, menunda adsorpsi karbohidrat, dan mengurangi peningkatan glukosa darah. Akarbose telah digunakan untuk pengobatan diabetes lebih dari 20 tahun yang lalu. Manfaat dari akarbose adalah memperlambat perkembangan diabetes dan mengurangi risiko penyakit kardiovaskular (Gupta et al. 2015, Harikumar et al. 2015, Marin-Penalver et al. 2016, Stubbs et al. 2017). Penggunaan obat ini harus dihindari bagi pasien dengan gangguan ginjal. Efek samping dari obat ini menyebabkan diare dan kembung (Olokoba et al. 2012).

\section{Analog peptida}

Inhibitor dipeptidil peptidase (Vildagliptin dan Sitagliptin) mempunyai mekanisme kerja menghambat kerja dipeptidil peptodase sehingga meningkatkan kadar inkretin darah. Fungsi enkretin meningkatkan sekresi insulin dan menekan sekresi glukagon. Analog peptida yang lain adalah gastrik inhibitori peptida (Eksenatida dan Liraglutida).

Agonis GLP (glucagon-like peptide) mengikat reseptor GLP pada membran sel $\beta$ pankreas sehingga meningkatkan sekresi insulin. GLP endogen mempunyai waktu paruh beberapa menit, demikian juga obat 
Tabel 3. Kelebihan dan kekurangan golongan obat antidiabetes (Olokoba et al. 2012, Chatterjee dan Davies 2015, Gupta et al. 2015, Harikumar et al. 2015, Marin-Penalver et al. 2016)

\begin{tabular}{|c|c|c|}
\hline Golongan obat & Kelebihan & Kekurangan \\
\hline $\begin{array}{l}\text { Sulfonilurea: } \\
\text { (glibenklamid, gliklazid, glimepirid, } \\
\text { gliburid, glipizid, tolbutamid) }\end{array}$ & $\begin{array}{l}\text { Meningkatkan sekresi insulin, } \\
\text { harga murah, } \mathrm{HbA} 1 \mathrm{C} \downarrow \pm 1 \%\end{array}$ & $\begin{array}{l}\text { Menyebabkan hipoglikemia, gagal } \\
\text { ginjal pada penderita lanjut usia }\end{array}$ \\
\hline 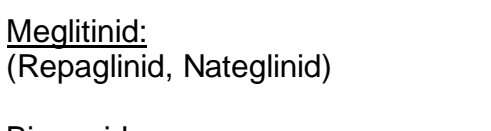 & $\begin{array}{c}\text { Meningkatkan sekresi insulin, } \\
\operatorname{HbA} 1 \mathrm{C} \downarrow 0,5-0,8 \%\end{array}$ & Waktu kerja singkat, mahal \\
\hline$\frac{\text { Biguanid: }}{\text { (Metformin, Fenformin, Buformin) }}$ & $\begin{array}{c}\text { Mengurangi sekresi glukosa } \\
\text { hepatik dan meningkatkan } \\
\text { penyerapan glukosa perifer, } \\
\text { menurunkan berat badan, harga } \\
\text { murah, HbA1C } \downarrow \pm 1 \%\end{array}$ & $\begin{array}{l}\text { Tidak digunakan pada penderita } \\
\text { gangguan ginjal dan hati }\end{array}$ \\
\hline $\begin{array}{l}\text { Tiazolidinedion: } \\
\text { (Rosiglitazon, Pioglitazon, } \\
\text { Troglitazon) }\end{array}$ & $\begin{array}{c}\text { Meningkatkan sensitivitas insulin, } \\
\text { mengurangi komplikasi } \\
\text { mikrovaskular, harga murah, } \\
\operatorname{HbA} 1 \mathrm{C}_{\downarrow} \pm 1 \%\end{array}$ & $\begin{array}{c}\text { Meningkatkan risiko kematian pada } \\
\text { penderita penyakit kardiovaskular, } \\
\text { edema, patah tulang, gagal jantung, } \\
\text { dan kanker }\end{array}$ \\
\hline$\frac{\text { Inhibitor a-hidroksidase: }}{\text { (Miglitol, Akarbose, Voglibose) }}$ & $\begin{array}{l}\text { Memperlambat pencernaan pati di } \\
\text { dalam usus halus sehingga } \\
\text { mengurangi peningkatan glukosa } \\
\text { darah, mengurangi penyakit } \\
\text { kardiovaskular, harga sedang }\end{array}$ & $\begin{array}{c}\text { Tidak diberikan pada penderita } \\
\text { gangguan ginjal }\end{array}$ \\
\hline$\frac{\text { Analog peptide: }}{\text { (Vildagliptin, Sitagliptin) }}$ & $\begin{array}{c}\text { Meningkatkan enkritin, } \mathrm{HbA} 1 \mathrm{C} \downarrow \\
0,8-1 \%\end{array}$ & Waktu kerja singkat, harga mahal \\
\hline Analog amylin: & $\begin{array}{l}\text { Menurunkan kadar glukosa darah } \\
\text { dan menurunkan berat badan, } \\
\qquad \mathrm{HbA} 1 \mathrm{C} \downarrow 1-1,5 \%\end{array}$ & $\begin{array}{c}\text { Harga mahal, diberikan secara injeksi } \\
\text { subkutan }\end{array}$ \\
\hline
\end{tabular}

agonis GLP ini sehingga kurang efektif (Harikumar et al. 2015, Marin-Penalver et al. 2016).

\section{Anolog amilin atau analog agonis amilin Anolog amilin atau analog agonis amilin mempunyai mekanisme memperlambat pengosongan lambung, memperlambat proses pencernaan makanan, dan menekan glukagon. Biasanya analog amilin diberikan melalui injeksi subkutan sebelum makan dan dapat digunakan untuk DMT1 dan DMT2. Obat ini selain menurunkan kadar glukosa darah juga dapat menurunkan berat badan (Gupta et al. 2015, Harikumar et al. 2015).}

\section{Non obat}

Program pendidikan untuk meningkatkan motivasi, keterampilan, perubahan gaya hidup, pemahaman diet, olah raga, dan pengobatan diabetes akan meningkatkan kualitas hidup penderita diabetes. Manfaat dari program ini adalah memahami pentingnya pengurangan asupan kalori, peningkatan aktivitas fisik, dan peningkatan pengetahuan tentang diabetes sehingga dapat menurunkan berat badan, mengurangi stress, mengurangi risiko penyakit kardiovaskular, dan mencegah terjadinya komplikasi (Chatterjee dan Davies 2015).

Perubahan gaya hidup untuk pengontrolan diabetes, di antaranya dengan mempelajari lebih banyak tentang diabetes, mendapatkan perawatan secara rutin, mempelajari cara mengontrol diabetes diri sendiri, memantau kondisi diabetes, dan memeriksa secara rutin untuk jangka panjang (Harikumar et al. 2015). Pasien secara aktif mengendalikan diri, memanfaatkan teknologi pemantauan dan pengobatan, dan berkomunikasi dengan dokter (Chatterjee dan Davies 2015). 
Diet dengan mengkonsumsi makanan tinggi serat dan rendah lemak bertujuan untuk menurunkan berat badan merupakan cara lain untuk meningkatkan sensitivitas tubuh penderita diabetes terhadap efek insulin (Harikumar et al. 2015). Diet yang tepat dapat mengontrol kadar glukosa darah dengan mengurangi hemoglobin terglikasi 1,0-2,0\% dan jika dikombinasi dengan manajemen diabetes akan mengurangi rawat inap penderita diabetes (Sievenpiper et al. 2018). Jenis dan jumlah kalori yang terkandung dalam makanan merupakan hal penting untuk memelihara kesehatan tubuh. Diet tinggi lemak jenuh menginduksi adaptasi metabolisme dengan mengubah sensitivitas insulin perifer, mengurangi sirkulasi lemak, dan menurunkan lipogenesis dan glikogenesis hati (Zierath 2019).

Olahraga secara rutin membantu mencegah dan mengontrol diabetes. Manfaat dari olahraga antara lain membantu menurunkan berat badan, mengurangi kadar glukosa darah, mengurangi kolesterol dan tekanan darah, mengurangi stres, meningkatkan sensitivitas insulin, dan meningkatkan biogenesis mitokondria (Harikumar et al. 2015, Zierath 2019).

\section{KESIMPULAN}

Diabetes merupakan penyakit kelainan metabolit dengan gejala utama berupa hiperglikemia. Penyakit ini menjadi permasalahan global, karena penderitanya terus meningkat dari tahun ke tahun. Diagnosis dan pengobatan yang tepat dapat menurunkan jumlah kematian akibat diabetes.

Penderita DMT1 tidak mampu memproduksi insulin sesuai kebutuhan tubuh akibat rusaknya sel $\beta$ pankreas sehingga memerlukan insulin dari luar tubuh. DMT2 dapat diobati dengan golongan obat sulfonilurea, meglitinid, biguanid, tiazolidinedion, inhibitor a-glikosidase, analog peptida, dan analog amilin. Sulfonilurea mempunyai kelebihan menurunkan kadar glukosa darah dengan meningkatkan sekresi insulin, harganya murah, dan menurunkan HbA1C sekitar $1 \%$. Kelemahan sulfonilurea menyebabkan hipoglikemia dan gagal ginjal pada penderita DM usia lanjut. Meglitinid mempunyai kelebihan menurunkan kadar glukosa darah dengan mekanisme kerja meningkatkan sekresi insulin dan menurunkan $\mathrm{HbA} 1 \mathrm{C}$ 0,5-0,8\%. Kelemahan meglitinid waktu kerja obat singkat dan harganya mahal. Biguanid mempunyai kelebihan menurunkan kadar glukosa darah dengan 2 mekanisme kerja, yaitu mengurangi sekresi glukosa hepatik dan meningkatkan penyerapan glukosa perifer, menurunkan berat badan, murah, dan menurunkan $\mathrm{HbA1C}$ sekitar $1 \%$. Kekurangan biguanid tidak dapat digunakan pada penderita gangguan hati dan ginjal. Tiazolidinedion mempunyai kelebihan dapat menurunkan kadar glukosa darah dengan meningkatkan sensitivitas insulin, mengurangi komplikasi mikrovaskular, harga murah dan menurunkan $\mathrm{HbA} 1 \mathrm{C}$ sekitar $1 \%$. Kekurangan tiazolidinedion meningkatkan risiko kematian pada penderita penyakit kardiovaskular, edema, patah tulang, gagal jantung, dan kanker. Inhibitor a-glikosidase mempunyai kelebihan dapat menurunkan kadar glukosa darah dengan memperlambat pencernaan pati di dalam usus halus dan mengurangi penyakit kardiovaskular. Kekurangan inhibitor a-glikosidase tidak dapat digunakan pada penderita gangguan ginjal. Analog peptida mempunyai kelebihan dapat menurunkan kadar glukosa darah dengan meningkatkan kadar inkretin dan menurunkan HbA1C 0,8-1\%. Kelemahan analog peptida mempunyai waktu kerja singkat dan harganya mahal. Analog amilin mempunyai kelebihan dapat menurunkan kadar glukosa darah dengan memperlambat pengosongan lambung, memperlambat proses pencernaan makanan, dan menekan glukagon. Kelemahan analog amilin harganya mahal dan diberikan secara injeksi subkutan. Metformin merupakan salah satu obat golongan biguanid yang menjadi pilihan utama untuk DMT2 karena efektif menurunkan kadar glukosa darah dengan 2 mekanisme kerja, yaitu mengurangi sekresi glukosa hepatik dan meningkatkan penyerapan glukosa perifer, aman untuk penderita DM tanpa gangguan hati dan ginjal, dan harganya murah.

\section{DAFTAR PUSTAKA}

Akcay MN, Karadeniz E, Ahiskalioglu A (2019) Bariatric/metabolic surgery in type 1 and type 2 diabetes mellitus. Eurasian $\mathrm{J}$ Med 51: 85-89. doi: 10.5152/eurasianjmed.2018.18298 
Aktar N, Qureshi NK, Ferdous HS (2017) Obesity: A review of pathogenesis and management strategies in adult. Delta Med Coll J 5: 35-48. doi: 10.3329/dmcj.v5i1.31436

Al-Lawati JA (2017) Diabetes mellitus: A local and global public health emergency! Oman Med J 32: 177-179. doi: 10.5001/omj.2017.34

Allen N, Gupta A (2019) Current diabetes technology: Striving for the artificial pancreas. Diagnostics 9: 31. doi: 10.3390/diagnostics9010031

Asmat U, Abad K, Ismail K (2016) Diabetes mellitus and oxidative stress - A concise review. Saudi Pharm J 24: 547553. doi: 10.1016/j.jsps.2015.03.013

Atkinson MA (2012) The pathogenesis and natural history of type 1 diabetes. Cold Spring Harb Perspect Med 2: a007641. doi: 10.1101/cshperspect.a007641

Basukala P, Jha B, Yadav BK, Shrestha PK (2018) Determination of insulin resistance and beta-cell function using homeostatic model assessment in type 2 diabetic patients at diagnosis. $J$ Diabetes Metab 9: 790 . doi: 10.4172/2155-6156.1000790

Baynest HW (2015) Classification, pathophysiology, diagnosis and management of diabetes mellitus. $J$ Diabetes Metab 6: 541. doi: 10.4172/2155-6156.1000541

Bergman M, Buysschaert M, Schwarz PE, Albright A, Narayan KV, Yach D (2012) Diabetes prevention: Global health policy and perspectives from the ground. Diabetes Manag 2: 309-321. doi: 10.2217/dmt.12.34

Bolla KN, Sri SKV, Varalakshmi KN (2015) Diabetes mellitus and its prevention. Int J Sci Technol Res 4: 119-125

Chatterjee S, Davies MJ (2015) Current management of diabetes mellitus and future directions in care. Postgrad Med J 91: 612-621. doi: 10.1136/postgradmedj-2014-133200

Chaudhury A, Duvoor C, Dendi VSR, Kraleti S, Chada A, Ravilla R, Marco A, Shekhawat NS, Montales MT, Kuriakose K, Sasapu A, Beebe A, Patil N, Musham CK, Lohani GP, Mirza W (2017) Clinical review of antidiabetic drugs: Implications for type 2 diabetes mellitus management. Front Endocrinol 8: 6. doi: 10.3389/fendo.2017.00006

Crofts CAP, Zinn C, Wheldon MC, Schofield GM (2015) Hyperinsulinemia: A unifying theory of chronic disease? Diabesity 1 : 34-43. doi: 10.15562/diabesity.2015.19

Deepthi B, Sowjanya K, Lidiya B, Bhargavi RS, Babu PS (2017) A modern review of diabetes mellitus: An annihilatory metabolic disorder. J In Silico In Vitro Pharmacol 3: 14. doi: 10.21767/24696692.100014

Duan W, Shen X, Lei J, Xu Q, Yu Y, Li R, Wu E, Ma Q (2014) Hyperglycemia, a neglected factor during cancer progression. Biomed Res Int 2014: 461917. doi: 10.1155/2014/461917

Forbes JM, Cooper ME (2013) Mechanisms of diabetic complications. Physiol Rev 93: 137188. doi: 10.1152/physrev.00045.2011

Forouhi NG, Wareham NJ (2014) Epidemiology of diabetes. Medicine (Abingdon) 42: 698-702. doi: 10.1016/j.mpmed.2014.09.007

Goguen J, Gilbert J (2018) Hyperglycemic emergencies in adults. Can J Diabetes 42 Suppl 1: S109-S114. doi: 10.1016/j.jcjd.2017.10.013

Gupta A, Sharma M, Sharma J (2015) A Role of insulin in different types of diabetes. Int J Curr Microbiol App Sci 4: 58-77

Harikumar K, Kumar BK, Hemalatha GJ, Kumar MB, Lado SFS (2015) A review on diabetes mellitus. Int $\mathrm{J}$ Novel Trends Pharm Sci 5: 201-217

Janez A, Guja C, Mitrakou A, Lalic N, Tankova T, Czupryniak L, Tabak AG, Prazny M, Martinka E, Smircic-Duvnjak L (2020) Insulin therapy in adults with type 1 diabetes mellitus: A narrative review. Diabetes Ther 11:387-409. doi: 10.1007/s13300-019-00743-7

Kabel AM, Altowirqi R, Al Thobiti $\mathrm{H}$, Althumali A, Alharthi E (2017) Pharmacological therapy of type 2 diabetes mellitus: New perspectives. EC Pharmacol Toxicol 4: 12-19

Kharroubi AT, Darwish HM (2015) Diabetes mellitus: The epidemic of the century. World J Diabetes 6: 850-867. doi: 10.4239/wjd.v6.i6.850

Kolb H, Martin S (2017) Environmental/lifestyle factors in the pathogenesis and prevention of type 2 
diabetes. BMC Med 15: 131. doi: 10.1186/s12916-017-0901-X

Kumar A, Mittal R, Naidu PS (2017) Insulin resistance: Recent advances in pathogenesis, molecular mechanisms and clinical relevance. EC Pharmacol Toxicol 4: 244-262

Mane K, Chaluvaraju Kc, Niranjan Ms, Zaranappa Tr, Manjuthej Tr (2012) Review of insulin and its analogues in diabetes mellitus. J Basic Clin Pharm 3: 283-293. doi: 10.4103/0976-0105.103822

Marin-Penalver JJ, Martin-Timon I, SevillanoCollantes C, Del Canizo-Gomez FJ (2016) Update on the treatment of type 2 diabetes mellitus. World J Diabetes 7: 353-395. doi: 10.4239/wjd.v7.i17.354

Messina J, Campbell S, Morris R, Eyles E, Sanders C (2017) A narrative systematic review of factors affecting diabetes prevention in primary care settings. PLoS One 12: e0177699. doi: 10.1371/journal.pone.0177699

Okur ME, Karantas ID, Siafaka PI (2017) Diabetes mellitus: A review on pathophysiology, current status of oral medications and future perspectives. Acta Pharm Sci 55: 61-82. doi: 10.23893/1307-2080.APS.0555

Olokoba AB, Obateru OA, Olokoba LB (2012) Type 2 diabetes mellitus: A review of current trends. Oman Med J 27: 269273. doi: $10.5001 /$ omj.2012.68

Papatheodorou K, Papanas N, Banach M, Papazoglou D, Edmonds M (2016) Complications of diabetes 2016. J Diabetes Res 2016: 6989453. doi: 10.1155/2016/6989453

Paschou SA, Papadopoulou-Marketou N, Chrousos GP, Kanaka-Gantenbein C (2018) On type 1 diabetes mellitus pathogenesis. Endocr Connect 7: R38R46. doi: 10.1530/EC-17-0347

Pasquel FJ, Umpierrez GE (2014) Hyperosmolar hyperglycemic state: A historic review of the clinical presentation, diagnosis, and treatment. Diabetes Care 37: 3124-3131. doi: 10.2337/dc14-0984

Pathak V, Pathak NM, O'Neill CL, GuduricFuchs J, Medina RJ (2019) Therapies for type 1 diabetes: Current scenario and future perspectives. Clin Med Insights Endocrinol Diabetes 12: 1179551419844521.

\section{$10.1177 / 1179551419844521$}

Patil SS, Mehta M, Thakare V, Shende S, Shirure PA, Swami OC (2017) Role of insulin in management of type 2 diabetes mellitus. Int J Res Med Sci 5: 2282-2292. doi: 10.18203/23206012.ijrms20172422

Piero MN, Nzaro GM, Njagi JM (2014) Diabetes mellitus - A devastating metabolic disorder. Asian J Biomed Pharm Sci, 04: 1-7. doi:10.15272/ajbps.v4i40.645

Punthakee Z, Goldenberg R, Katz P (2018) Definition, classification and diagnosis of diabetes, prediabetes and metabolic syndrome. Can J Diabetes 42: Suppl 1: S10-S15. doi: 10.1016/j.jcjd.2017.10.003

Rhee SY, Kim YS (2015) Peripheral arterial disease in patients with type 2 diabetes mellitus. Diabetes Metab J 39: 283-290. doi: 10.4093/dmj.2015.39.4.283

Russell WR, Baka A, Bjorck I, Deizenne N, Gao D, Griffiths HR, Hadjilucas E, Juvonen $\mathrm{K}$, Lahtinen S, Lansink $\mathrm{M}$, Loon LV, Mykkanen $\mathrm{H}$, Ostman $\mathrm{E}$, Riccardi G, Vinoy S, Weickert MO (2016) Impact of diet composition on blood glucose regulation. Crit Rev Food Sci Nutr 56: 541-590. doi: 10.1080/10408398.2013.792772

Saeedi P, Petersohn I, Salpea P, Malanda B, Karuranga S, Unwin N, Colagiuri S, Guariguata L, Motala AA, Ogurtsova K, Shaw JE, Bright D, Williams R (2019) Global and regional diabetes prevalence estimates for 2019 and projection for 2030 and 2045: Results from the international diabetes federation diabetes atlas, $9^{\text {th }}$ Edition. Diabetes Res Clin Pract 157: 107843. doi: 10.1016/j.diabres.2019.107843

Setty SG, Crasto W, Jarvis J, Khunti K, Davies MJ (2016) New insulins and newer insulin regimens: A review of their role in improving glycaemic control in patients with diabetes. Postgrad Med J 92: 152-164. doi: 10.1136/postgradmedj-2015-133716

Sievenpiper JL, Chan CB, Dworatzek PD, Freeze C, Williams SL (2018) Nutrition therapy. Can J Diabetes 42: S64-S79. doi: 10.1016/j.jcjd.2017.10.009

Silver B, Ramaiya K, Andrew SB, Fredrick O, Bajaj S, Kalra S, Charlotte BM, Claudine K, Makhoba A (2018) EADSG guidelines: Insulin therapy in diabetes. 
Diabetes Ther 9: 449-492. doi: 10.1007/s13300-018-0384-6

Sorli C (2014) New developments in insulin therapy for type 2 diabetes. Am J Med 127: S39-S48. doi: 10.1016/j.amjmed.2014.07.006

Stubbs DJ, Levy N, Dhatariya K (2017) Diabetes medication pharmacology. BJA Education 17: 198-207. doi: 10.1093/bjaed/mkw075

Suprapti B, Widyasari N, Rahmadi M, Wibisono C (2017) Review of insulin therapy in type 2 diabetes mellitus ambulatory patients. Indones J Pharm 28: 221-231. doi: 10.14499/indonesianjpharm28iss4pp221

Uusitupa M, Khan TA, Viguiliouk $E$, Kahleova $H$, Rivellese $A A$, Hermansen $K$, Pfeiffer A, Thanopoulou A, Salas-Salvado J, Schwab U, Sievenpiper JL (2019) Prevention of type 2 diabetes by lifestyle changes: A systematic review and meta-analysis. Nutrients 11: 2611. doi: 10.3390/nu11112611

Wang CY, Neil DL, Home P (2018) 2020 vision - An overview of prospects for diabetes management and prevention in the next decade. Diabetes Res Clin Pract 143: 101-112. doi: 10.1016/j.diabres.2018.06.007

WHO (2019) Classification of diabetes mellitus 2019. World Health Organization, Geneva

Wondafrash DZ, Desalegn TZ, Yimer EM, Tsige AG, Adamu BA, Zewdie KA (2020) Potential effect of hydroxychloroquine in diabetes mellitus: A systematic review on preclinical and clinical trial studies. J Diabetes Res 2020: 5214751. doi: $10.1155 / 2020 / 5214751$

Wu Y, Ding Y, Tanaka Y, Zhang W (2014) Risk factors contributing to type 2 diabetes and recent advances in the treatment and prevention. Int J Med Sci 11: 1185-1200. doi: $10.7150 / \mathrm{ijms} .10001$

Zierath JR (2019) Major advances and discoveries in diabetes - 2019 in review. Curr Diab Rep 19: 118. doi: 10.1007/s11892-019-1255-x 